\title{
VERBS OF LOCOMOTION LIKE ИДТИ (TO GO) - ХОДИТЬ (ТО WALK): SOME THOUGHTS ON THEIR SEMANTIC DESCRIPTION
}

\author{
Nezrin Samedova
}

Samedova, N. Verbs of locomotion like идти (to go) - ходить (to walk): some thoughts on their semantic description // Lege artis. Language yesterday, today, tomorrow. The Journal of University of SS Cyril and Methodius in Trnava. Warsaw: De Gruyter Open, 2013, vol. 1 (1), June 2016. - p. 309-358. DOI: 10.1515/lart-2016-0007 ISSN 2453-8035

\begin{abstract}
The author presents the analysis of discussions about the semantic description of traditionally postulated verbs of locomotion like $u \partial m u$ /to go/ - xодumb /to walk/. The analysis reveals that there are very few ideas on the nature of the verbs that are uncontroversial. The second objective of the author is to propose a theory that not only incorporates ideas of several generations of eminent researchers but is also consistent within itself, comprehensive and as simple as possible.
\end{abstract}

Keywords: verbs of directional locomotion like $u д m u$, verbs of non-directional locomotion like $x о д и m b$, homogeneous transitive verbs of locomotion like $u \partial m u_{1}$ and like $x о \partial u m b_{1}$, homogeneous intransitive verbs of locomotion like $u \partial m u_{2}$ and like $x о \partial u m b_{2}$, non-homogeneous transitive verbs of locomotion like идтиз and like ходитьз, non-homogeneous intransitive verbs of locomotion like идmu4 and like xодить4.

\section{Introduction}

Traditionally postulated verbs of locomotion like $u \partial m u$ (to go) - xoдumb (to walk) remain an exciting puzzle. The problem of their semantic description has a long tradition of fruitful investigation, cf.: "This closed class of verbs... can be argued to be one of the most thoroughly researched and scrupulously described verb classes in the field of Slavic linguistics" (Hasko 2010: 207). Nevertheless, representatives of various theories and schools turn to it time and time again, see, for instance, (Зализняк, Микаэлян, Шмелёв 
2015; New approaches to Slavic verbs of motion 2010).

There are very few ideas on the nature of these verbs that are not debated in existing literature (see the first chapter of the present article where I delineate the state of the art of the issue). Remarkably, the literature discusses even the choice of a term for referring to them. Traditionally, the term "глаголы движения" is used, cf., e.g., (Грамматика русского языка 1953; Грамматика современного русского литературного языка 1970; Маслов 2004; Петрухина 2012; Русская грамматика 1980). However, as Isachenko rightly points out, this term also embraces verbs like нагибаться, махать, кивать, дрыгать (Исаченко 1960: 309). Isachenko therefore proposes the term "глаголы перемещения" (Ibid.: 310), cf. also (Апресян 1995a; Апресян 1995b; Гловинская 2001; Майсак, Рахилина 1999; Маслов 2004; Окано 2015; Петрухина 2012: 162, 189; Плунгян 2011;). Karcevski, meanwhile, used the term "глаголы передвижения" (Карцевский 2000: 170; Карцевский 2004c: 127 et seq.; Карцевский 2004a; Карцевский 2004b). This term appears to be the most apt choice from both a semantic and stylistic (cf. the characterization of the verb nеремещяаться as "канцелярский" in (Рахилина 2000: 224), cf. also (Rakhilina 2004: 2)) perspectives.

The aim of the paper is both to analyse the state of the art of the problem and to propose such a semantic description of verbs like $и д m u-x о д и m b$ that will be consistent within itself, comprehensive and as simple as possible. With this end in view, I examine the problem in the light of exceptionally keen and profound remarks by Maslov. I will attempt to show that due attention should be given to the scholar's ideas.

The solution is developed on the material of Russian verbs of locomotion. To be precise, I consider, so to say, "primary verbs of locomotion" like the traditionally postulated verbs идти and ходить. There are grounds to think that the results obtained can be extrapolated 
to the rest of Russian locomotion verbs.

Throughout the investigation, we have consistently applied the classical structuralist methods of distributional analysis (cf. Апресян 1990; Кобозева 2000) and oppositional analysis (cf. Кобозева 2000; Сусов 1999) and the general method of system analysis (cf. (Ломтев 1976)). Through these methods, we have investigated distributive potential of verbs we postulate, identified their differential semantic features and defined their place in the system of the Russian language.

\section{The state-of-the-art: the wealth of ideas and the lack of consensus}

A review of studies by several generations of eminent researchers in one article cannot be anywhere near comprehensive. I will therefore have to confine myself to systematizing analysis of extremely valuable discussions that have nourished the solution I propose in Section 3.

\subsection{Reasons for the separation of verbs like uдти - ходить}

Researchers unanimously characterize these verbs as a small group that is a closed, absolutely unproductive system holding a very important place in the general system of the Slavic verb (Исаченко 1960: 309), cf. also (Зализняк, Микаэлян, Шмелёв 2015: 99; Карцевский 2004c: 136; Hasko 2010: 207).

According to Isachenko, these words were separated out from all Russian verbs on principle by Shaxmatov (Исаченко 1960: 310-311). This class is, as Hasko and Perelmutter put it, "...notorious among Slavic linguists for their idiosyncratic behavior in their lexical, semantic, syntactical, and aspectual characteristics..." (Hasko, Perelmutter 2010: 2-3). Therefore, the question arises how exactly these units differ from the rest of locomotion verbs. 
In Isachenko's view, the most distinguishing feature of the verbs examined is their peculiar "pairedness" (Исаченко 1960: 310). See also (Hasko 2010: 207): "The rigid boundaries for inclusion into the... group of motion verbs are based on a seemingly isolated "pairedness" phenomenon". Researchers unanimously agree that these verbs come under two types / sets / (parallel) series (Грамматика русского языка 1953; Исаченко 1960: 311; Карцевский 2000: 170; Карцевский 2004c: 61, 101, 136; Окано 2015), see also (Шахматов 1941a: 191). They are pairs of verbs (Русская грамматика 1980: 590; Милославский 1999; Русский язык 1998), two-term correlations (Грамматика современного русского литературного языка 1970: 345), two closed classes of words the elements of which are in a one-to-one correspondence (Зализняк, Микаэлян, Шмелёв 2015: 99). In Karcevski's opinion, the "peculiarity of these verbs is their determinacy or indeterminacy with regard to space... This new meaning unknown to the rest Russian verbs is the reason why locomotion verbs is a separate small system" (Карцевский 2004c: 136), cf. (Ibid.: 61). See also (Шахматов 1941a: 191). In (Исаченко 1960: 310) it is pointed out that terms of the pairs are semantically and morphologically correlated. The scholar specifies that the verbs $и д т и$ and ходить "differ from the mass of the rest verbs in that they refer to the same way of movement ("walking") but each "stylizes" the process in its own way in regard to its happening in space" (Ibid.: 309-310). Cf. (Грамматика современного русского литературного языка 1970: 345): they are "opposed by their meaning", "correlative by real meaning and derivation". See (Русская грамматика 1980: 590): a stable group with structural and semantic features. In (Русский язык 1998: 87), we find the following rationale: "Setting of these verbs as a special group is accounted for both by the nearness of their lexical meaning and by common derivational and grammatical properties that distinguish these verbs from other ones". Kagan provides another motivation: "Typically, for a given verb, all the different usages of imperfective aspect involve exactly the same form. Verbs of manner of motion are special in this 
respect, since they have two distinct imperfective forms, determinate and indeterminate, which divide their aspectual functions in a certain way" (Kagan 2010: 145). Janda gives the following ground: "The difference between motion and non-motion verbs is that nonmotion verbs can be ambiguous for Completability, whereas motion verbs have two stems that unambiguously mark this distinction" (Janda 2010: 131). On the other hand, Miloslavskiy believes that the verbs under discussion are segregated by no means on semantic ground: "If to apply the semantic principle of separating this group of motion verbs consistently, then the group will include significantly more verbs: двигаться, перемещаться, скользить, подниматься, еtс." (Милославский 1999: 547). The linguist thinks that the verbs discussed are segregated by a morphological principle (Ibid.: 547). "The thing is that the second term of the pairs бежать - бегать, гнать-гонять, катить - катать and alike has the suffix - $a-$. Usually indicating the imperfective aspect this suffix gives a special attribute to motion these verbs denote" (Ibid.: 547).

Researchers point out an interesting fact: "...This group of paired verbs of motion has become known as glagoly dvizheniia 'The verbs of motion' in Slavic linguistic and pedagogical literature" (Hasko 2010: 207), cf. (Плунгян 2011: 331). In other words, the group has not received its own label as yet. We know of only three attempts of the kind. Karcevski named its terms "глаголы передвижения" (Карцевский 2000; Карцевский 2004), Isachenko termed them as "глаголы перемещения" (Исаченко 1960: 310) and Kagan refers to them as "verbs of manner of motion" (Kagan 2010). Let us also remark that Hasko uses, among others, the expression "paired unprefixed verbs of motion" for denoting these verbs (Hasko 2010: 207).

\subsection{Terms employed for differentiating verbs like идти and ходить}

Meanwhile, a variety of terms has been proposed to capture the idiosyncrasy of verbs like идти and verbs like ходить. Most of them describe the former as possessing positive 
semantic feature, whereas the latter are characterized negatively: "определённомоторный / неопределённо-моторный" (Маслов 2004: 32, 393; Шахматов 1941а: 191), "глаголы определённого / неопределённого движения" (Зализняк, Микаэлян, Шмелёв 2015; Карцевский 2000: 171; Карцевский 2004c: 101 et seq.), cp. "определённые / неопределённые глаголы перемещения" (Маслов 2004: 393, 394, 453), "однонаправленный / ненаправленный" (Исаченко 1960: 311; Маслов 2004: 328, 393, 394, 496), "однонаправленный / неоднонаправленный" (Грамматика современного русского литературного языка 1970: 345; Русская грамматика 1980: 591; Русский язык 1998: 87), "направленное / ненаправленное движение" (Зализняк, Микаэлян, Шмелёв 2015: 115-117; Панов 1999: 181-182), "целенаправленное / нецеленаправленное движение" (Зализняк, Микаэлян, Шмелёв 2015: 110, 115, 338), "детерминативный / недетерминативный" (Окано 2015), ср. (Карцевский 2004c: 121), "determinate / indeterminate" (Jaкobson 1984; Dickey 2010; Janda 2010), "determinate / indeterminate imperfective aspect" (Kagan 2010); "unidirectional / nonunidirectional" (Hasko 2010; Koptjevskaja-Tamm, Divjak, Rakhilina 2010; Nesset 2010). On the contrary, it is significantly more seldom when the second term of the pairs is described positively, while the first term of these pairs is named negatively: "моторнократный / моторно-некратный подвид" (Шахматов 1941b: 474) (cf. Апресян 1995a; Апресян 1995b; Гловинская 2001; Маслов 2004: 129, 393; Плунгян 2011: 332), "кратный" / "некратный подвид" (Грамматика русского языка 1953: 461). Finally, very occasionally, both types of verbs are denoted by positive terms: "однонаправленный" (Карцевский 2004с: 102; Карцевский 2004a: 227) and "разнонаправленный" (Карцевский 2004c: 102, 121; Карцевский 2004a: 228), cf. (Зализняк, Микаэлян, Шмелёв 2015: 114; Плунгян 2011: 332) (note, however, Maslov’s comment "not so apt" about the term "разнонаправленный" (Маслов 2004: 394)). 
2.3 The semantic descriptions of the specificity of verbs like uдти-xодить

One can already judge by terminology that linguists understand the specificity of verbs like $и д т и$ - ходить differently. Indeed, if each term of these pairs is treated as semantically marked or unmarked, then there are four logically possible approaches to interpreting the meaning of these correlates and, remarkably, the literature contains all

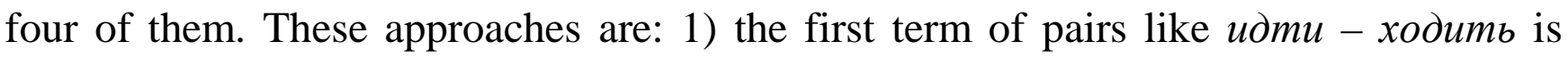
marked, while the second one is unmarked; 2) the first term is unmarked, whereas the second one marked; 3) both terms are marked; 4) both terms are unmarked. However, as one will see, the precise qualification of theories is not always achievable. On a related note, the reader will also see that terms used by researchers are not always congruent to the definitions suggested.

2.3.1 The approach "The first term of pairs like uдmu-xодumb is marked, while the second one is unmarked"

According to Karcevski's weighty opinion (cf. (Исаченко 1960: 311)), verbs examined are distinguished in the following. First, their meaning contains "...determination, positive or negative, with regard to the notion of space: лететь includes the notion of direction, летать, in contrast, presents zero degree of direction" (Карцевский 2004c: 61). Verbs like лететь can be used only when the direction of movement is known. For instance, Птиць летят means that the direction of their flight is known to the speaker (e.g., they can see where the birds are flying) (Карцевский 2000: 171), cf. (Карцевский 2004c: 137). Verbs of indeterminate motion, on the contrary, never allow indicating the direction of motion precisely enough. Thus, Птиць летают над озером means that the birds fly in various directions. If to say Птиць летают вон $к$ тому дереву, we understand that they fly there and back several times (Карцевский 2004c: 137), cf. (Карцевский 2000: 171). Second, verbs of determinate motion "make to think" not only about the direction of movement but also about time. The scholar notes that both phrases 
Когда я шёл вчера в школу, я встретил приятеля аnd Когда вчера я ходил в школу, я встретил приятеля are "absolutely correct, but it is not specificated in the second phrase whether I met a friend on my way there or back" (Карцевский 2004c: 137). The linguist similizes semantic difference between verbs under review to the relation between a genus and a species. Thus, летать corresponds to the genus of locomotion, meanwhile лететь is the realization of the genus of locomotion, its special case (Ibid.: 61). When we say рыбы плывут, птицы летят, etc., this means an implementation of one of various ways of locomotion and this inevitably makes us think about a concrete setting, such as the direction of motion and time (Ibid.: 136-137). When differences between these two types of verbs disappear, the general (возить, носить) and the concrete (вести, нести) coincides in one concrete case of actualization: "Thus, one can say both equally: Лотадь везёт (more concrete and individually...) оr возит (the generalized nature) до шести седоков..." (Ibid.: 137).

The authors of (Грамматика русского языка 1953: 461) carried on the classical tradition. In their view, the compared terms differ in several semantic features (see Исаченко 1960: 311). Verbs like $и д т и$ refer to an action that proceeds in one direction, ceaselessly and at the determined moment. Ходить and such like denote an action that happens not in one direction or not on a single occasion, not at the same time.

Isachenko suggested regarding only directionality of motion in space as the decisive semantic criterion that contrasts verbs like $и д т и$ to verbs like ходить. The former ones are verbs of unidirectional nature of motion. They denote movement in one direction. As for the latter, the scholar objects to treating them as multidirectional. He recons these verbs as the weak term of the opposition and names them non-directional (Исаченко 1960: 311312): "...Their general meaning does not contain positive indications to the direction of motion" (Ibid.: 311); "unlike verbs like $и д т и$, verbs of the series ходить simply do not 
signal unidirectionality of motion. It means that in concrete cases verbs of the series ходить can refer both to motion in one direction (Он ходит в школу через парк) and to motion in various directions (Он ходит по лесу)" (Ibid.: 311-312).

Like Isachenko, Hasko points out that the paired verbs "essentially state the same type of motion manner, but still provide different information about the motion event..." (Hasko 2010: 207). She thinks that the opposition has different facets but "the primary meaning common to one group of these verbs is the idea of motion in one direction, while the verbs serving as their paired counterparts lack this meaning of unidirectionality..." (Ibid.: 207). Thus, the class of motion verbs formally expresses / marks the idiosyncratic encoding of unidirectionality and non-unidirectionality of motion in space. She concludes that (non)unidirectionality is obligatorily expressed in Russian when certain common types of motion events are described (e.g., motion on foot, swimming, running, driving) (Ibid.: 208).

We find similar ideas in (Nesset 2010): "...Unidirectional verbs like idti are used about motion in one direction towards a goal" (Ibid.: 353), "...the meaning of idti... involves two components: motion on foot at normal speed and motion in one direction towards a goal" (Ibid.: 355). Meanwhile "the non-directional motion verbs are used whenever we are not dealing with motion in one direction..." (Ibid.: 353). Nesset concludes that nondirectional verbs are semantically unmarked, as the non-directional verbs are compatible with different kinds of situations, and as these verbs are used when directionality is irrelevant. He claims that "unidirectional verbs like idti, on the other hand, must be specified for directionality" (Ibid.: 355).

In Dickey's view, "...the opposition determinate/indeterminate distinguishes between motion occurring along a single goal-directed trajectory (determinate) versus motion not 
consisting of a single goal-directed trajectory (indeterminate)" (Dickey 2010: 68). He supposes that "determinate motion as a conceptual category is relatively unproblematic and probably universal in languages of the world. However, the category of indeterminate motion is unusual, if not unique, from the perspective of linguistic typology" (Ibid.: 68). To his knowledge, the meaning of verbs like xoдumb is "unattested as a special, formally marked category outside Slavic" (Ibid.: 69). The linguist claims that verbs like xodumb "are unusual as a special class" (Ibid.: 69), cf. also: "the functionally peculiar class" (Ibid.: $67)$.

2.3.2 The approach "The first term is unmarked, whereas the second one marked" Peshkovskiy finds additional semantic features in the meaning of verbs like xodumb. Having compared the verbs летит and лemaem he concludes that "the meaning of the root $л е m$ - is the same in both verbs: locomotion in the air by using wings" (1956: 104). However in the verb летаem "...something is added by the suffix -a-. Namely, first of all it is indicated that motion does not happen ceaselessly, that not all the time of performing the motion is entirely filled with this motion; лemaem means "flies" hither and thither, makes circles, perhaps even stops for some time, etc. (Ibid.: 104-105). Besides that, in close relation to these breaks in motion there is a necessity of some special duration of motion (Ibid.: 105). The scholar sums up: in the verb лemamb "...the whole process is denoted as fragmenting into parts during the time of its happening and by this reason demanding certain duration" (Ibid.: 105).

\subsubsection{The approach "Both terms are marked"}

The view seems to be prevailing. Shakhmatov describes the first ones as denoting motion that proceeds in one or another determined direction and, importantly, at the determined moment (Шахматов 1941a: 191). The scholar comments on the illustration Он ехал: "just then" (Ibid.: 191). As for the second ones, they denote an action that is ceaseless but, 
nevertheless, indicating discrete indetermined moments (Ibid.: 190-191). Он ходит по комнате is interpreted as "moves around a room in various directions, perhaps stopping from time to time and interrupting the motion" (Ibid.: 190-191). Cf. the comment on $O H$ ездит по этой дороге: "not now, not at the moment, but at different times" (Ibid.: 191).

From Panov's perspective, directional verbs (like $u \partial m u$ ) show that the action happens in one direction, whereas non-directional verbs (xодumb and alike) show that the action is performed in various directions, i.e. in various places or back and forth (1999: 181).

The last two academic grammars have exactly the same take on the issue, so (Русская грамматика 1980) is only quoted here: "These words are opposed on the semantic features 'unidirectionality' - 'non-unidirectionality' and 'non-repetitiveness' 'repetitiveness"' (Ibid.: 591); "non-unidirectional verbs... name motion that happens in various directions, in many cases it is repeated: Boт бегает дворовыий мальчик... (Ibid.: 594). Cf. the identical ideas in (Русский язык 1998: 87): "The first terms... refer to an action that happens in one direction and on a single occasion (without interruptions), the second ones... denote an action that is performed in various directions or regularly repeated..."

Here is the place to introduce Okano's interpretation. It combines the approaches of all three academic grammars. To her mind, $и \partial m u$ and such like express movement in one direction that happens once and at one moment (Я иду в школу) and verbs like ходить describe locomotion in various directions that is repeated and happens not once (Я хожу в школу) (2015: 204).

Miloslavskiy also sees more than one distinctive feature. The definition of xодumb and alike is "...motion that either happens in determined direction many times, repeated 
motion, or unsystematic motion, multidirectional one" (1999: 547). Идти and similar verbs refer to singular or unidirectional action (Ibid.: 547).

Apresjan consistently develops the idea he set forward in (1967: 113). The scholar objects to the definitions of verbs like xoдumb that contain reference to the corresponding verb and some more or less standard addition (1995c: 35), e.g., something like "xoдumb = 'is the same as $и д m u$ with the difference that ходиmь denotes motion that is repeated, that happens in various directions and at different times'..." (Ibid.: 35). In (Апресян 2013) he gives completely independent names and interpretations to lexemes he ascribes to the verbs бежать and бегать. Below we reproduce the linguist's thoughts about those lexemes that are of interest for this article.

The names and meanings of the lexemes of the verb бежать. 1.1. 'to move by running in а place': Олени бегут на водопой (Ibid.: 62); meaning: A1 runs in A2 from A3 over A4 for (doing) A5 'Entity A1 moves by running in place A2 from place A3 over surface A4 for purpose A5' (Ibid.: 63). 1.2 'to participate in a race': бежать марафон (Ibid.: 62); meaning: A1 runs A2 'Human being A1 is a participant of tournament of kind A2 or for distance A2 that is a track event, speed skating or cross-country skiing and covers the distance in time A3' (Ibid.: 65).

The names and meanings of the lexemes of the verb бezamb. 1.1. 'to move by running in various directions': бегать по двору туда и сюда (Ibid.: 55); the meaning: A1 runs about A2 'Entity A1 moves by running over surface or in space A2, usually in various directions A3' (Ibid.: 55). 1.2 'move by running there and back': бегать утром на море; Сбегай за хлебом (Ibid.: 55); meaning: 'Human being or animal A1 running or walking very fast moves to place A2 from place A3 over surface A4 for purpose A5 and then returns to A2' (two-way action) (Ibid.: 57). 1.3 'to go for running': Он бегает на длинные дистанциии 
(Ibid.: 55); meaning: A1 runs A2 'Human being goes for running A2 as a sportsman' (Ibid.: $58)$.

\subsubsection{The approach "Both terms are unmarked"}

The idea that both terms are unmarked is supported by Kagan. She advances the hypothesis that "determinate and indeterminate verbs do not differ in terms of their lexical meaning but have different aspectual usages..." (2010: 141). She holds that indeterminate aspect is "semantically compatible with the single, unidirectional motion event reading" (Ibid.: 148), so "determinate verbs stand in an aspectual competition with the indeterminates" (Ibid.: 142). By way of evidence, Kagan analyses negative, interrogative and some types of affirmative sentences to show that they do not entail event plurality: Лена (ещё) не ездила в деревню; Tы (когда-нибудь) ездил вдоль этого берега?; Он уже плавал вниз по реке; Мы уже бегали наперегонки (от ворот до фонтана); Лена уже летала во Франциию; Я уже водила Димину новую машину. Он дал мне проехать от офиса до магазина (Ibid.: 148-150). She thinks that compatibility with the adjunct odin raz (once) "makes it especially clear that the indeterminate verb is compatible with a single event interpretation" (Ibid.: 150): Однажды я уже ходил по этой тропинке; Я тогда прошёл по ней от подножия до ручья, а потом свернул на другую дорогу; $Я$ экстремал... Один раз плавал буквально наперегонки с акулой. ...Я молотил по воде руками и ногами изо всех сил, чтобы добраться до берега быстрее; Один раз ездил

с Курием на поезде по маршруту Москва-Петрозаводск... Вернее, два раза обратно Петрозаводск-Москва тоже в поезде ехал (Ibid.: 150-151).

\subsection{The "two-way motion" meaning}

In their descriptions of verbs like xодumb researchers point to a meaning that is defined as "motion performed in two directions: Он ходил в город и принёс газету (Исаченко 1960: 312), "motion in two directions, i.e. "there and back" (Ibid.: 324), "two-way action" 
(Маслов 2004: 577), "two-way directed (there and back)" (Апресян 2011: 7), "two-way directed movement" (Ibid.), "goal-directed action that presupposes reversible movement of a subject to another point" (Зализняк, Микаэлян, Шмелёв 2015: 100), "a roundtrip" (Janda 2010: 131), "'movement back and forth', i.e., movement to a goal and back again" (Nesset 2010: 354); cf. (Апресян 2013: 55, 57; Гловинская 2001: 182, 243, 247; Грамматика современного русского литературного языка 1970: 346; Kagan 2010: 154; Русский язык 1998: 87). See also the comments in (Janda 2010): "Among the possible interpretations of the indeterminate stems is that of repeated roundtrips, as in deti xodjat $v$ školu 'the children attend school (i.e., go there and back repeatedly)'. An indeterminate stem thus can express a collection of repeated cycles, each of which brings the individual back to their original location" (Ibid. 131); "the indeterminate verb letat ${ }^{\prime I}$ 'fly' can refer to a series of roundtrips, from which it is possible to extract a single roundtrip..." (Ibid. 128-129).

Isachenko explicates $Я$ сегодня ходил в город as follows: "The form has complex meaning: it informs (1) that the doer walked to the town and (2) that they returned" (1960: 324). The scholar emphasizes that this meaning does not contradict the general meaning of non-directional verbs 'the absence of signaling the directionality of movement"' (Ibid. 324). Nesset points out another aspect: "The 'back and forth' type explains the widespread use of non-directional motion verbs for repeated events. In order to go to the movie theater again..., one has to go back home before repeating the event" (2010: 354).

Judging by the literature, verbs can have the meaning under review when they are in specific grammatical forms. These are the preterit (Исаченко 1960: 324; Маслов 2004: 577; Русский язык 1998: 87), the past participle (Маслов 2004: 577), the future tense (Ibid.: 577). Thus, Maslov quotes examples provided by Forsyth: Через сиену проходит Фирс, ездивший встречать Любовь Андреевну; Ты ведь недолго будешь ходить "... 
(Platonov - the words are addressed to a person who has to go to the post office and at once return)" (Ibid.: 577). Glovinskaja, however, believes that a movement verb has the meaning only when it is able to occur with the expression of the final point or purpose and only if "...the relevant valency is materialized...": Я ходил сегодня в магазин (2001: 182).

As for the nature of the meaning, Isachenko qualifies it as one of six particular and additional meanings that, however, in distinction from the others, is related to "the specific character of action denoted by movement verbs" (1960: 312). According to (Грамматика современного русского литературного языка 1970: 346), it is a particular grammatical meaning. Apresjan postulates it as an independent meaning of polysemous verbs like xodumb $(1967,1995 c, 2013)$ that should be separated in a dictionary entry $(2011: 7 ; 2013$ : 56), cf. (1967: 113).

The scholar thoroughly substantiates his view (Апресян 2013). In his description, the meaning under consideration belongs to the lexeme бегать 1.2 and it is distinct from the lexeme бezamb 1.1 in quite a few essential characteristics. The linguist lays special emphasis on the following ones (cf. (Ibid.: 51)):

1. Бегать 1.1 can be used in actual-durative meaning, but бегаmь 1.2 cannot (see also (Ibid.: 57));

2. Бегать 1.2 has the form $\approx$ PERFECTIVE (Сбегай за газетой), but бегать 1.1 does not;

3. Бегать 1.2 has the valences of the initial point (бегать с работы <из общежития>), the final point (бегать в детский сад $\left.<_{в} \kappa л у б>\right)$ ) and a purpose (бегать за газетами $<н а$ занятия>, бегать купаться), but бегать 1.1 does not have these valences;

4. Бегать 1.1 has the valence "various directions" (mуда и сюда, туда-сюда, туда и обратно, из конца в конец, от письменного стола к книжному шкафу, etc.), but 
бегать 1.2 does not have it;

5. Бегаmь 1.1 can be used in the absolutive construction, especially in combinations with evaluative adverbs (хорошо <плохо $>$ бегает), but for бегать 1.2 absolutive usage is impossible;

6. The synonyms of бегать 1.1 are носиться, летать, coll. гонять; the synonym of бегать 1.2 is xодиmb;

7. The derivatives of бегать 1.1 are беготня, бегающий (бегающие птищь моа), забе^гаmь and some others; бегать 1.2 does not have these derivatives.

Besides that, in other work the researcher notes that the form "IMPERFECTIVE PRESENT" of the verb бегать 1.2 always has the resultative meaning and hence has reduced "semantic paradigm", i.e. it is only possible in the praesens historicum, usual and iterative meanings (2011: 7).

Apresjan points to the impossibility of making explicit the general rule that will allow deducing all seven characteristics inherent in бегаmь 1.1 from the characteristics бегаmb 1.2 has, or vice versa. It is this point he regards as a ground for qualifying these two entities as different lexemes of the verb бегать (2013: 51). He also indicates that some phrases typical for бегать 1.1 and бегать 1.2 are incompatible: "...Cf., for instance, the deviance *Дети бегали по двору купаться, *Девушки бегали в клуб туда и сюда, etc...." (Ibid.), see also (1995c: 36).

However, there is quite a different approach developed by Kagan. She agrees that indeterminate verbs can be used to encode a whole trip. It happens when "a shift in meaning (possibly coercion) takes place, whereby such phrases come to be used to encode a trip as a whole - which includes motion in two directions as well as, most crucially, the intermediate state of the subject occupying the goal location" (2010: 159). For instance, one may utter "Лена ходила на почту" with the intention to communicate that Lena has 
been at the post office (Ibid.: 159). However, such examples "exhibit a special usage of indeterminate verbs, one that goes beyond their original semantics and involves some kind of shift in the meaning of the V or VP" (Ibid.: 160). The linguist thinks that there is a need for a detailed investigation that will address the question of how exactly a VP that originally denotes an event of motion conventionally comes to be used to encode a trip, of which this event of motion constitutes the first stage (Ibid.).

As for the cases like (Один раз) Лена уже летала во Францию, here "...VPs containing an indeterminate verb and a goal phrase are associated with the "there and back" reading for pragmatic reasons" (Ibid.: 159), "...this component is not entailed by VPs..." (Ibid.: 154). Kagan substantiates her thesis with the following reasons (apart from those ones reviewed in 2.3.4.). First, the "back motion" meaning component does not (or at least is much less likely to) arise in sentences that do not contain a goal phrase. Second, the sentence is true even if Lena went to France by plane but went back by train. Also, if such sentences (cf. Я не летала в Париж) are negated, negation facts prove that the affirmative sentences entail only the "there" event. Furthermore, the fact that sentences under discussion do not entail the "back motion" is supported by native speakers' judgments. When asked if Lena, who has come to Paris by Austrian Airlines, is eligible for participation in a lottery announced by Austrian Airlines (Каждый, кто летал в Париж "Австрийскими авиалиниями", может участвовать в лотерее), all Kagan's informants gave a positive answer, despite the fact that Lena is assumed to be still in Paris and not to have flown away (Ibid.: 155-156).

\subsection{The feature "telicity"}

The literature addresses one more aspect of the meaning of the verbs at hand. It is the semantic characteristic that is traditionally termed as "telicity". 
The investigation of the feature was pioneered by Maslov. The scholar proceeds from the idea that "the opposition of telicity and atelicity usually materializes in a language as the opposition of the meaning of different verbs and in some cases as the opposition of different meanings of the same verb as well" (Маслов 2004: 315). Hе adopts the opinion that it is essential to differ telic and atelic verbs and verbs that are dual in regard to the feature of telicity / atelicity (Ibid.: 28). He also describes the latter as verbs with the changing meaning in this regard (Ibid.: 315); ones that have either telic or atelic meaning (Ibid.: 32); telic and atelic meanings are combined in them (Ibid.: 30), cf. (Ibid.: 264, 266). In some works the scholar notes that there are many cases of the kind (Ibid.: 315, 388). See also "...In many cases the distinction T: AT (telicity: atelicity - N.S.) proves to be internal, it separates different meanings of the same verb" (Ibid.: 555-556), cf. (Ibid.: 557).

Maslov indicates that the occurrence of one or the other meaning in "dual" verbs is determined in every case of their use by surrounding context (Ibid.: 264). "...A verb that is atelic in the absolutive usage becomes telic in combination with complements of certain kind or with adverbials of the purpose (bound) of motion" (Ibid.: 30), see also (Ibid.: 315).

The scholar interprets the locomotion verbs in the light of this approach. He unequivocally classes verbs like $u д т и$ as "dual" (Ibid.: 32), cf. (Ibid.: 79). Thus, "in the absolutive usage" they are atelic: идти (быстро, медленно, etc.) (Ibid.: 315-316), cf. (Ibid.: 556, 79). Their correlative perfectives with the prefix no- are ingressive verbs: "In this cases the corresponding perfective derivatives пойти, понести, поехать, попльть, побежать, etc. are ingressive verbs that in substance are the same as полюбить, забарабанить, заходить, забегать; cf. the quotation from Mayakovsky: ...лошадь рванулась, встала на ноги, ржанула и пошла..." (Ibid.: 79), see also (Ibid.: 32). If verbs like идти осcur with adverbials of the purpose of motion ( $и д у$ в город), then they are telic (Ibid.: 458, 315, 318, 556). Thereafter "...derivatives with no- usually lose their ingressive meaning 
and we get purely aspectual pairs: идти на собрание / пойти на собрание, ехать в Москву / поехать в Москву..." (Ibid.: 79-80), see also (Ibid.: 32, 318).

As for xодumb and alike, in most cases the scholar qualifies them as atelic (Ibid.: 30, 32, 79). However, in his 1958 article we find the remarkable idea: "Telic meanings can occur in certain contexts not only in unprefixed determined verbs (пииу письмо, иду в город) but also in indetermined ones (он каждый день ходит в университет)" (Ibid.: 458).

Here is the place to quote also Maslov's reflections on relations of the category "telicity / atelicity" and the category "determinacy / indeterminacy":

"...There is a subtle but essential difference between the category T: AT and the category of "determinate" and "indeterminate" verbs. In particular, "determinate" verbs can be both telic (for example, in the context that indicates the final purpose of motion) and atelic (время идет, бежит, вчера я ехал в автобусе, etc.). The meanings "concrete motion", "singular motion" and even "spatial 'unidirectionality' of motion" are by no means the same as the meaning "tending toward the bound, toward the critical point when having achieved which an action ought to 'get exhausted' and stop" (Ibid.: 556557).

The scholar's approach has partly influenced the last Academic grammar. It describes both идти and ходить as imperfectives that are non-correlative as they are atelic (Русская грамматика 1980: 592, 595): "The atelic meaning blocks formation of aspectual pairs..." (Ibid.: 592). Interestingly, however, these two types of verbs are treated very differently. Xodumb and such like are interpreted in full conformity with the definition of noncorrelative imperfectives, namely: they are atelic verbs and they never form aspectual pairs (Ibid.: 591, 594). The same cannot be said for the interpretation of verbs like $u \partial m u$. It is stated that these are telic verbs that denote such a motion that is directed to achieving the bound (when these words are employed in their direct meaning, the bound is spatial): бежать (к финишу), везти (поклажу домой), вести (ребенка в школу), гнать (собаку на улииу), ехать (в Москву), идти (в магазин) (Ibid.: 595). Nevertheless, they have "monoaspectual" nature, as their lexical meanings always change when these 
imperfectives combine with prefixes (идти - прийти, дойти, уйти, отойти). These verbs have no purely aspectual prefix (Ibid.: 595). It is emphasized that they derive ingressive perfectives with the prefix no- that remain non-correlative perfectives (Ibid.: 591), cf. (Ibid.: 595, 597). On the other hand, only a note says that "unidirectional verbs can be used in atelic meaning as well: Хорошо бежать полями". In such cases they remain non-correlative imperfectives" (Ibid.: 595).

It has to be said that the literature holds scanty comments on the semantic aspect at hand. Thus, in (Шелякин 2001) we find only the remark "can be contextually telic and atelic" (2001: 89) and two examples provided for both cases: telic идти в школу (Ibid.: 89) and atelic идти по улиие (Ibid.: 92). Zaliznyak and Shmelev only point out that verbs like xодиms are telic in the type of usage when they indicate non-goal-directed motion (ходить по комнате, бегать по двору...) (Зализняк, Микаэлян, Шмелёв 2015: 100). As for the type of usage when the same verbs indicate goal-directed motion that presupposes reversible movement of a subject to another point, the scholars do not comment on it (Ibid.: 100). However, they note that in this meaning indetermined imperfectives are the aspectual correlates of prefixed perfectives like cxодить, съездить, etc. (Ibid.: 100).

Janda rejects the traditional concepts of telicity and atelicity. She employs the concepts of Completability / a Completable situation and non-Completability / a non-Completable situation (2010: 132). She specifies that completability is unlike telicity and boundedness. It "...refers to both imperfective and perfective situations" (Ibid.: 132). It appears, however, that the content of the concepts she has introduced is quite traditional, cf.: "A Completable situation is one that makes progress and will usually reach a natural conclusion if it is continued, whereas a Non-completable situation is one that can be engaged in without necessarily making any progress" (Ibid.: 129-130). See also "Most 
Russian verbs are ambiguous in their expression of Completability, as we see in igrat ${ }^{\prime I}$ 'play', which can be Completable when one is playing a piece of music, but can be Noncompletable if one is just amusing oneself" (Ibid.: 130). The linguist writes the following about the verbs we are interested in: "Completability vs. non-Completability is actually the same as the determinate vs. indeterminate distinction. What is special about motion verbs is that they have taken this semantic distinction to the level of a lexical / morphological formal distinction, specializing one set of verbs (determinate stems) for Completable functions and another set (indeterminate stems) for Non-completable functions" (Ibid.: 130). Thus, we can claim that as a matter of fact, Janda characterizes verbs like $и д т и$ and ходить as non-homogeneous and homogeneous respectively (i.e. as telic and atelic, in line with the traditional terminology).

\subsection{Correlative perfectives}

Linguists thoroughly investigate correlative perfectives of the verbs at hand. As one can see already from the previous sections of our review, two types of the perfectives are the focus of much attention. In the case of verbs like $u \partial m u$, these are perfectives with the prefix no- (nойтu and alike). As for the verbs like ходиmь, these are perfectives with the prefix $c$ - (cxoдumb and alike). The following two subsections deal with the existing descriptions of these perfectives.

\subsubsection{The perfective 'noümu'}

Judgments expressed about perfectives like noŭmu create a contradictory picture. On the one hand, it is widely stated that the verbs possess the meaning 'beginning', cf., e.g., (Грамматика русского языка 1953: 464; Грамматика современного русского литературного языка 1970: 347; Зализняк, Микаэлян, Шмелёв 2015: 102, 116; Карцевский 2004c: 127; Маслов 2004: 79; Русская грамматика 1980: 591; Русский язык 1998: 87;). It is noted that they can be substituted with the construction 
начать + ИНФ: Он побежал быстрее $=$ Он начал бежать быстрее (Петрухина 2012: 197).

On the other hand, according to (Русская грамматика 1980), they "... always express the merging of the beginning of an action with the subsequent action, the unity of the beginning and the further process of an action (Ibid.: 597); they mean "the beginning and continuation of an action as a single entity that is not divided into phases (the meaning "achieving a result in the process of emerging of an action)..." (Ibid.: 596-597).

At the same time, researchers that attribute the meaning 'beginning' to the perfectives point out explicitly or implicitly that it can be absent. Cf.: "The preterit of some intransitive movement verbs (пошёл, поехал, полетел) loses the meaning 'beginning' in certain contexts..." (Исаченко 1960: 319); "the preterits like пошёл usually express initial accomplishment..." (Ibid.: 319), cf. (Ibid.: 322); "...derivations with no- usually loses their meaning 'beginning'...: идти на собрание / пойти на собрание, ехать в Москву / поехать в Москву..." (Маслов 2004: 79-80); "...the meaning 'beginning' of such motion verbs is weakened" (Зализняк, Микаэлян, Шмелёв 2015: 116). Interestingly, the authors use quotation marks when writing about the meaning 'beginning': "в 'начинательном' значении" (Ibid.: 115).

As a result, one can read in the literature that "...such verbs cannot be transformed into the construction with the verb начать... (Русская грамматика 1980: 597); "... побежал домой cannot be substituted with *Он начал бежать домой..." (Петрухина 2012: 197); "...nойти в кино, поехать в Париж... does not mean exactly 'начать <идти, ехать, etc.>"' (Зализняк, Микаэлян, Шмелёв 2015: 116).

However, these perfectives acquire "somewhat different meaning, cf. Его нет дома: он 
пошёл в город" (Исаченко 1960: 319). As in (Русская грамматика 1980: 596, 597), this meaning is described by means of the concept of result: "The preterits поехал и полетел are also employed in the meaning of result, cf. Он вчера поехал (полетел) в Москву" (Исаченко 1960: 319); "The infinitive nойти has almost lost the meaning 'beginning', but retains the meaning of result" (Ibid.: 322). The scholar sums up his observations by stating: "... Only two accomplishments are derived from unidirectional verbs of movement (the series $u д т и$ ): they are the ingressive one (я попльвв) and the resultative one, and in some cases the borderline between them disappears (cf. я пойдy)" (Ibid.: 322).

In (Зализняк, Микаэлян, Шмелёв 2015) the meaning of пойти and alike is explicated through the following examples:

"When we wonder who поведёт машину, повезёт детей в школу..., we mean an action itself rather than the beginning of the action. The verb which first meaning is 'to start < doing something >' turns out to be kind of substitute of an action in its entirety. Though it is possible поити в кино, а по дороге передумать, можно поехать в Париж и с полдороги вернуться..., the language disregards all these circumstances, since it takes it as the norm that an action, if it has been started, will be accomplished" (Ibid.: 116).

The scholars think that this is the essence of the ingressive meaning. It just indicates to the fact that an action has started (will start) and, if so, it is more than likely that it will materialize (Ibid.: 116).

"...The ingressive meaning in some sense locks into the resultative one: the beginning of a situation turns out to be equivalent to its realization. This duality of the ingressive meaning explains the ambiguousness existing in the literature in respect to the treatment of some verbal classes (such verbs, indeed, unite both ingressive and resultative aktionsarts)" (Ibid.: 117).

The linguists relate metamorphoses that happen to the meaning of the verbs examined with the presence of adverbials of purpose (иду в город) (Маслов 2004: 458, 315, 318, 556), cf. (Исаченко 1960: 319). Isachenko also notes the infinitive: "The infinitives like nоехать, побежать, поплыть, полететь retain to a greater or lesser extent a shade of ingressivity" (1960: 321); "the infinitive noŭmu has almost lost the ingressive meaning but retains a shade of resultativeness" (Ibid.: 322). 
A number of researchers conclude that pairs like $и д m u-n o u ̈ m u$ are purely aspectual (Маслов 2004: 79-80), see also (Ibid.: 32, 318). Meanwhile in (Зализняк, Микаэлян, Шмелёв 2015: 117) it is claimed that not all pairs of the type are purely aspectual.

Observations in (Зализняк, Микаэлян, Шмелёв 2015) are of special interest. They are about verbs like ковылять, рысить, скакать, etc. that denote motion performed in a specific way and that can be both directional and non-directional, in the researchers' opinion. Zaliznyak and Shmelev point out that the verbs derive both inchoative and ingressive aktionsarts, in other words, they derive initial perfectives both with the prefix 3a- and with the prefix no- (Ibid.: 116).

"...Interestingly, in the context of the inchoative $3 a$ - they indicate first and foremost to the specific way of motion, and in the context of the ingressive no- they point to its directionality, cf.: Он заскакал на одной ноге and Он поскакал к дому" (Ibid.: 116). The researchers note that "...in the context of the ingressive no- even verbs that originally do not have the meaning of directional motion can acquire it, cf.: Он похромал к дому (i.e. 'пошёл, хромая)" (Ibid.: 115).

Finally, we would like to draw researchers' attention to an extremely thought-provoking remark made by Isachenko. He notes that perfectives like nоехать, побежать, полететь and like съездить, сбегать, слетать "соmpete" with each other (1960: 322). Thus, the scholar poses a serious problem of the nature of semantic difference between these two types of verbs.

\subsubsection{The perfective 'cxodumb'}

In the case of the verb ходumb and such like, their strong semantic similarity with correlative perfectives of the type cходиmь is pointed out. Cf.: "...its meaning comes up very closely..." (Исаченко 1960: 312); "the PERFECIVE forms of these verbs almost do not differ semantically from the IMPERFECTIVE forms, both are resultative..." (Апресян 2011: 7). See also the usage of the symbols $\cong$ (Гловинская 2001: 182, 243, $247)$ and $\approx$ (Апресян 2013: 51, 57) in the description of their relationships. 
Indeed, one can see the familiar judgments: the meaning "movement 'in two directions'" (Исаченко 1960: 324); "...they denote the sum of two phases of motion: 'there and back"' (Ibid.: 324); motion there and back (Карцевский 2004c: 101), cf. (Ibid.: 138; Зализняк, Микаэлян, Шмелёв 2015: 127); "in the phrase сходить на nочmy the variety of directions reduces itself to two opposite movements: there and back.." (Карцевский 2004a: 228); an action that presupposes reversible movement of a subject to another point" (Зализняк, Микаэлян, Шмелёв 2015: 100); the meaning "two-way movement" (Апресян 2011: 7); a two-way action (Апресян 2013: 57); the meaning "two-way (there and back) movement (2013: 74); motion performed there and back (Грамматика русского языка 1953: 603); sxodit' 'go somewhere and come back' (Janda 2010: 125 et seq.). See Isachenko's reasoning: "The command Сходи в аптеку contains not only the appeal to cover the way to the purpose indicated but also the explicit appeal for returning. The form Я съездил в Москву ... can be used only by the person who is not in Moscow at the moment" (1960: 324).

As regards the difference in the meaning of these correlatives, it is related to the meaning 'singularity' (Апресян 2013: 57; Зализняк, Микаэлян, Шмелёв 2015: 127; Исаченко 1960: 322, 323; Маслов 2004: 392; Русский язык 1998: 87), see also the term "Single Act Perfective" in (Janda 2010: 131 et seq.). Here is how Isachenko explicates the difference: "The form сходил form explicitly presents the action as a singular movement 'in two directions', meanwhile the form ходил that denotes the same action says nothing about its 'singularity'" (1960: 324).

Apresjan employs the concept of resultativity as well: "The IMPERFECTIVE forms are resultative only in the sense of executing an action but not in the sense of achieving the result of the action; cf.: Сегодня уже четыре раза ходил за хлебом, и все без толку. Meanwhile the PERFECTIVE forms, in full conformity with the PERFCTIVE meaning, denote achieving the result of the action: Сходил за хлебом means that he brought it (2011: 7). 
Cf. (2013: 57): "... сбегал за газетами (газеты куплены или извлечены из почтового ящика и принесены домой), позавтракал и помел на работу". The linguist argues that the verbs under discussion can be regarded as inexact PERFECTIVE forms of corresponding unprefixed verbs, as they retain the main element of the PERFECTIVE meaning, namely, indication to the resultativity of an action; cf. бегал в киоск за газетой (может быть, купил, а может быть и нет) VS сбегал в киоск за газетой (бегал и купил)" (Ibid.: 74).

The researcher reveals two more differences. One of them is also of semantic nature: the perfectives "...denote an action executed for a shorter time interval; cf.: бегал за газетой - сбегал за газетой, летал в Лондон - слетал в Лондон" (Ibid.: 74). The other one is stylistic: perfectives are of "a more colloquial nature", than corresponding unprefixed imperfectives (Ibid.: 74).

As one can see, it is not without reason that the question about the status of paradigms like ходить / сходить is answered differently. On the one hand, in (Зализняк, Микаэлян, Шмелёв 2015: 100) it is argued that ходить and alike verbs are the imperfective correlates of cxodumb and such like. As evidence, Maslov criterion is employed: "...The verbs cxодить <за хлебом>, сбегать <за сигаретами>, съездить <в отпуск> in the iterative context will be substituted with xодumb, бегаmь, ездить, respectively $(\mathrm{OH}$ каждое утро ходит за хлебом)..." (Ibid.: 214). In (Апресян 2011: 7) the author recognizes the pairs as aspectual as well. He argues that it is a new type of aspectual opposition that has not been described in aspectology yet.

On the other hand, in (Апресян 2013: 74) сходить and alike are treated as inexact perfective forms of corresponding unprefixed imperfectives on the ground that the perfectives retain resultativity which is the main semantic element of perfectivity. 


\subsection{The aspectological approach}

The puzzling nature of traditionally postulated verbs like $и д т и$ and ходить leads linguists to the conclusion that it can be explained from the perspective of aspectology.

This belief has continued since at least Shakhmatov's works; see the terms "моторнократный / моторно-некратный подвид" (1941b: 474). Peshkovskiy was another classic scholar who supported the tradition. Thus, he explains what the category of aspect is, through comparing the verbs лететь and летать. In his view, they represent an easier aspectual category than the perfective and imperfective categories (2001: 104). Cf. also (Jakobson 1984: 29-30).

Modern researchers employ the following expressions when dealing with the verbs: special aspectual subsystem (Зализняк, Микаэлян, Шмелёв 2015: 99); formally express an aspectual opposition (Плунгян 2011: 332); indeterminate aspectuality, indeterminate Aktionsart (Nichols 2010: 47); the special aspect-like category of indeterminacy (Ibid.: 59), a quasi-aspectual distinction (Dickey 2010: 69); primarily aspectual in nature (Ibid.: 89); determinate / indeterminate aspect (Kagan 2010); sub-aspectual nature (Hasko 2010: 207). See also: "grammaticalised (opposition)" (Dickey 2010: 69; Koptjevskaja-Tamm, Divjak, Rakhilina 2010: 317).

Kagan develops a theory according to which the verbs discussed in addition to the typical perfective / imperfective opposition, exhibit a further aspectual distinction (2010: 141). The linguist treats indeterminate as the default aspect that does not impose any semantic constraints on the aspectual properties of the predicate (Ibid.: 142). She thinks it compatible with any aspectual interpretation (Ibid.: 148). To her mind, whatever definition of imperfectivity is suggested, "indeterminate aspect should be treated as an instance of the "ordinary" imperfective, whereas determinate verbs are characterized by 
special aspectual properties" (Ibid.: 152). In particular, she specifies that "indeterminate aspect is compatible with a wider range of aspectual interpretations" (Ibid.: 146).

Researchers' reasoning is deeply rooted in their approaches to aspectuality, so it is not possible to present even a relatively complete picture of it in this review. Hence the mosaic structure of the rest of the section.

In Zaliznyak and Shmelev's opinion, verbs under consideration have a peculiar relation to aspectual correlativity (2015: 99). Second, the semantic relationship between the members of the pairs discussed "...reminds the relations between imperfective and perfective members of an aspectual pair and morphologically indetermined verbs are derived from determined ones by means of the same mechanisms that derive imperfective correlates in aspectual pairs" (Ibid.: 99).

Kagan believes that a wide range of usages these verbs are associated with are aspectual by nature. For indeterminate verbs these are iterativity, habituality, motion in multiple directions, and naming the type of motion (2010: 141). For instance, Маша ходила по парку out of context "may report a single event of Masha walking about in the park, i.e. walking here and there in various directions. It may also receive a habitual reading, according to which Masha used to walk in the park in the past, or a (non-habitual) iterative reading, meaning that Masha walked in the park more than once" (Ibid.: 142).

\section{According to Perelmutter,}

"...simplex (unprefixed) motion verbs are deviant in that they are usually grouped not in pairs, but in groups of three: for example, the basic meaning 'to go' can be expressed by the perfective pojti 'to go.PF', determinate imperfective idti 'to go in a single direction.DET.IMPF', and indeterminate imperfective xodit' 'to go in multiple directions. INDET.IMPF"' (2010: 166).

\subsection{The challenge to a researcher}

Thus, a researcher who ventures studying Russian locomotion verbs encounters a situation

that is as extremely privileged as extremely complex. On the one hand, abundance of 
brilliant observations and ideas makes one think it sufficient just to reap the harvest of previous investigations. On the other hand, these observations and ideas belong to proponents of such different, sometimes even diametrically opposed viewpoints that one wonders to what extent they are compatible.

\section{The proposed solution: the differentiation of homonymous locomotion verbs}

The suggested solution is based on Maslov's idea ${ }^{1}$ we have set forth above that a locomotion verb can have both homogeneous and non-homogeneous meanings. While I completely and unconditionally accept the essence of the idea, I will express it in the terms of the theory I follow. The theory states that two homonymous locomotion verbs should be differentiated, one of which is homogeneous and the other one is non-homogeneous. In other words, in contrast to the traditional approach, the theory postulates not two separate meanings but two words in their own rights ${ }^{2}$.

However, it is only a part of the developed solution. We also show that the currently accepted approach creates an inaccurate picture of the fragment of the verbal system when

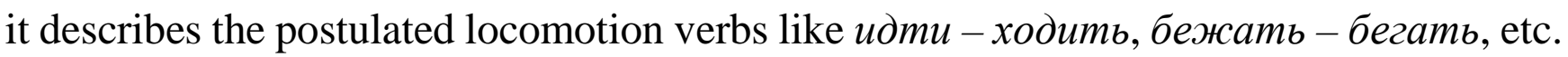
as intransitive, cf., e.g., (Грамматика современного русского литературного языка 1970: 347; Словарь современного русского литературного языка 1991: 382, 392; Dickey 2010; Nesset 2010). The thing is, in Russian it is completely grammatical to say, for instance, идти / ходить пять километров. Cf. also Karcevski's brief remark: "Locomotion verbs... can be accompanied by an adverbial complement of measure in accusative case, for example, идти всю ночь, ехать сотню вёрст..." (2004c: 111).

Thus, if the traditional description postulates one intransitive verb, in my perspective, instead one should differentiate four following verbs: homogeneous transitive, homogeneous intransitive, non-homogeneous transitive and non-homogeneous intransitive. I substantiate the thesis through describing four homonymous directional 
verbs $и д m u$ and four homonymous non-directional verbs $x о д u m b^{3}$. A separate subsubsection is devoted to the description of each of these eight verbs. For clarity, I show the core of the proposed solution in a table the cells, which indicates numbers of these subsubsections. Thus, the table will also serve as a kind of road map to assist with orientating in the structure of the rest of the article.

Table 1. The proposed solution: the road map.

\begin{tabular}{|c|c|c|c|}
\hline \multicolumn{2}{|c|}{ Characteristic } & Directional verb & Non-directional verb \\
\hline \multirow{2}{*}{$\begin{array}{l}\mathscr{0} \\
0 \\
\mathscr{\Xi} \\
0 \\
0 \\
0 \\
0\end{array}$} & transitive & 3.1.1. & 3.2.1. \\
\hline & intransitive & 3.1.2. & 3.2.2. \\
\hline \multirow{2}{*}{$\begin{array}{l}0 \\
0 \\
0 \\
\tilde{\Xi} \\
0 \\
0 \\
0 \\
0 \\
\vdots \\
0\end{array}$} & transitive & 3.1.3. & 3.2.3. \\
\hline & intransitive & 3.1.4. & 3.2.4. \\
\hline
\end{tabular}

The table also allows noting that each directional homonym has its non-directional counterpart, and vice-versa. Below one will see that these counterparts have almost identical semantic descriptions. We qualify the fact as evidence of "the pairedness phenomenon" noticed by the traditional approaches.

\subsection{The homonymous directional verbs 'uдmu'.}

All four homonyms described below are characterized with the non-grammatical seme 'directed locomotion of a certain type'. Note that the superscript capital tags $\mathrm{H}, \mathrm{NH}, \mathrm{T}$, IT stand for the terms "homogeneous", "non-homogeneous", "transitive" and "intransitive", 
respectively.

\subsection{1 Идти Н.Т.}

Идти ${ }^{\text {H.T. }}$ obligatorily requires the direct object that is expressed explicitly or implicitly and indicates distance: Он тогда еще работал учителем в районной школе и каждый день щел до работы пятнадиать километров по степи (Edootoj boo); Для того чтобы более свободно идти первый круг или первый километр дистанщии, в разминку включаются семенящая ходьба и ускорения 3-4 раза по 60-100 м. (The system of sportsmen training in racewalking). It is not used in the actual-durative meaning. It does not combine with phrases "(preposition) $з a+$ duration". It correlates with the ingressive perfective пойти: Либо ты сейчас подтянешься больше, чем я, на турнике, либо пойдешь пять километров гусиным шагом (Russian National Corpus - hereinafter RNC); Слез я в темноте и пошёл километра 3 через лес по тропинке к месту сбора... (Message board); Упустив грузинский автобус и отбиваясь от назойливых таксистов, мы пошли пешком километра четыре, убедились, что дальних машин нет (Лапшин). In some contexts the perfective can be substituted with the constructions $c m a m b+И Н Ф$ and начаmь $+И Н Ф$.

\subsection{2 Идти ${ }^{\text {H.IT. }}$}

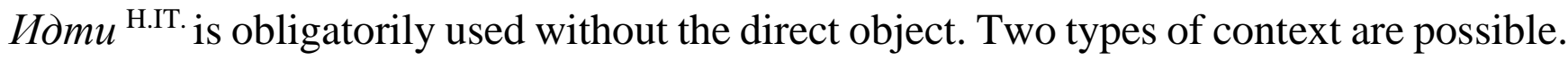
One is when the verb occurs absolutively: Иду по улице и по сторонам смотрю. На то и столица, чтоб по сторонам смотреть (RNC). The other is when the verb is used

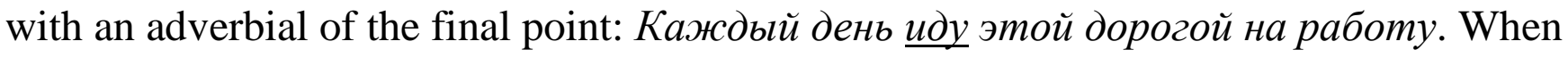
used absolutively, it can have the actual-durative meaning. It does not combine with phrases "(preposition) $з a+$ duration". It correlates with the ingressive perfective noümu. The perfective can be substituted with the constructions cmamb начать $+И Н Ф$, cf.: Много было неловкого, неискреннего, смутного, но все 
чувствовали, что мы тронулись, что пошли и идём (RNC) // ...стали / начали идти...; Это такая обычная история, что мне было бы даже лень её рассказывать, если б Слон убежал днём и пошёл по улицам, мешая автобусам, троллейбусам, заходя в магазины и удивляя прохожих (RNC) // ...стал бы / начал бы идти... However, this substitution is not always possible: Ксана уступила, пошла за ним, но шла неохотно... (RNC); Mы ㅁоли по проспекту Мира, шли долго, все измерзли и выили к ледяному Енисею (RNC).

\subsection{3 Идти ${ }^{\text {NH.T }}$}

Идти ${ }^{\text {NH.T. }}$ obligatorily requires the direct object that is expressed explicitly or implicitly and indicates distance: На чемпионате мира я шёл с ним (эту дистанцию) в одном заходе (by analogy with the example in (Апресян 2013: 66) На чемпионате мира $я$ бежал с ним в одном забеге...). It can be used in the actual-durative meaning: Смотри: он идёт уже третий круг. It combines with phrases "(preposition) за + duration": идти стометровку за 50 секунд. In such cases the verb is not used in the actual-durative meaning. It correlates with the final perfective пройти: Либо ты сейчас подтянешься больше, чем я, на турнике, либо пройдешь пять километров гусиным шагом (by analogy with the example in 3.1.1); пройти стометровку за 50 секунд.

\subsection{4 Идти ${ }^{\text {NH.IT. }}$}

Идти ${ }^{\text {NH.IT. }}$ obligatorily requires the explicit or implicit indication of the final point (note

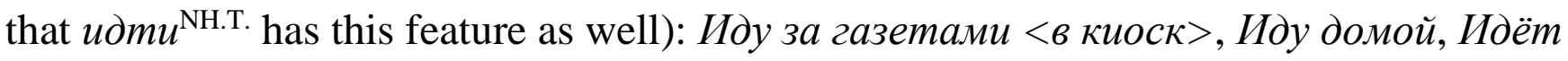
на короткую дистанциию. It can be used in the actual-durative meaning: Смотри: он идёт к двери. No cases of its combining with phrases "(preposition) з $a+$ duration" have come to our notice. It correlates with final perfectives prefixes of which denote spatial direction: отойти, уйти, выйти, прийти, etc. 
3.2 The homonymous non-directional verbs 'xodumb'.

The four homonyms possess the non-grammatical seme 'non-directed locomotion of a certain type'. Note that the same superscript capital tags H, NH, T, IT are used here.

\subsection{1 Ходить ${ }^{\text {H.T. }}$}

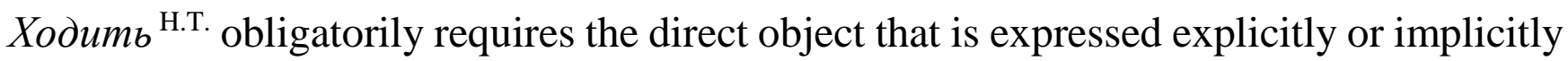
and indicates distance: Каждый день ходит 5 километров. It is not used in the actualdurative meaning: - Где тьл? - *Хожу пять километров (Though, however, -Где тыз? - Да вот, хожу свои пять километров is completely acceptable). It does not combine with phrases "(preposition) $3 a+$ duration". It correlates with the perfectives зaxodumb, omходить, nоходить, проходить. I have a real example only for one of them: $\mathrm{Mbl}$ честно отходили свои километры и заслужили хороший обед (The letter has called for the journey. The royal path), cf. закончили ходить. However we can model, e.g., $И$ когда вы заходили свои пять километров? by analogy with Выйдя замуж, она заварила cynь (Зализняк, Микаэлян, Шмелёв 2015: 115). One can see that the perfective can be substituted with the constructions cmamb $+x o d u m b$ and rayamb+ xодить.

\subsection{2 Ходиmь ${ }^{\text {H.IT. }}$}

Ходиmь ${ }^{\text {H.IT. }}$ is obligatorily used without the direct object. Two types of context are possible. The one is when the verb occurs absolutively: "Смотрите! - хотелось кричать ему. - Яххожу по улице без мамы и папь" (RNC). The other is when the verb is used with an adverbial of the final point: Каждый день хожу этой дорогой на paбomy. When used absolutively, it can have the actual-durative meaning. It does not combine with phrases "(preposition) $3 a+$ duration". It correlates with the perfectives заходить, отходить, походить, проходить. All of them are frequently used. The perfective заxодumb can always be substituted with the constructions cmamb $+x o d u m b$ 
and начать + ходить, cf.: Он встал и заходил по комнате (RNC) // ...стал / начал $\underline{\text { xodumb.... }}$

\subsection{3 Ходить ${ }^{\text {NH.T. }}$}

Ходиmь NH.T. obligatorily requires the direct object that is expressed explicitly or implicitly and indicates distance, cf. the constructed example: Он ходил стометровку, когда я увидел его в первый раз. It can be used in the actual-durative meaning (cf. the illustration above). It combines with phrases "(preposition) $3 a+$ duration": xодumb стометровку за 50 секунд. In such cases the verb is not used in the actual-durative meaning. It correlates with the final perfective проходить: ...Проходив по полям километров двадиать и, вернувшись в лагерь ни с чем, обнаруживаешь у товарища десятка полтора добытых перепелов, которых четко сработал его курихаар... (Hunting dogs: A brief decsription); ...Мне обычно удается разносить (обувь), проходив несколько километров с мучительной болью (Ballet flats Ronzo - review).

\subsection{4 Ходить ${ }^{\text {NH.IT. }}$}

Ходиmb ${ }^{\text {NH.IT. }}$ obligatorily requires the explicit or implicit indication of the final point (note that ходить Nн.T. has this feature as well): *Ходить за газетами $<_{8} \kappa и о с к>$, *Ходить в магазин, *Ходить на короткую дистанцию. The sentence *Ходил по тропинке is acceptable only if it is an elliptical counterpart of Ходил по тропинке к морю. It cannot be used in the actual-durative meaning. More importantly, all the illustrations above are not employed, that is why they are asterisked. It seems that the only type of context where this verb is used is the imperative under negation. Cf. (a) and (b):

(а) Быстро иди домой! Нет, стой! Не иди! -

(b) *Быстро ходи домой! Нет, стой! Не ходи!

One can even argue that the form He xodu! occurs more frequently than the form He udu! Remarkably, the data we have obtained from the Russian National Corpus (as of mid-July 
2016) corroborates our hypothesis. To receive the data, I have intuitively chosen the most employed locomotion verbs that are postulated by the existing tradition. They are in quotation marks, since only the acoustical complex without referring to meaning was taken into consideration. As for the interpretation of the data, the following regularities call attention to themselves:

- The affirmative form of a directional verb always occurs significantly more often than its negative form;

- The affirmative form of a non-directional verb always occurs significantly more seldom than the same form of its directional counterpart;

- The negative form of a non-directional verb is almost always employed more often than the same form of its directional counterpart.

See the table for the precise data:

Table 2. The frequency of the imperative forms

\begin{tabular}{|l|c|c|c|}
\hline \multicolumn{1}{|c|}{$\begin{array}{c}\text { the form } \\
\text { the verb }\end{array}$} & affirmative & negative & the proportion \\
\hline "Идти" & 53983 & 936 & $57.6: 1$ \\
\hline "Ходить" & 1784 & 1666 & $1.07: 1$ \\
\hline "Бежать" & 3524 & 103 & $34.21: 1$ \\
\hline "Бегать" & 145 & 115 & $1.26: 1$ \\
\hline "Плыть" & 258 & 5 & $51.6: 1$ \\
\hline "Плавать" & 32 & 6 & $5.3: 1$ \\
\hline "Лететь" & 1274 & 22 & $57.9: 1$ \\
\hline "Летать" & 86 & 12 & $7.17: 1$ \\
\hline "Нести" & 1040 & 20 & $52: 1$ \\
\hline "Носить" & 615 & 92 & $6.69: 1$ \\
\hline
\end{tabular}

I suppose that the data are related to the quantitave research by Perelmutter in (Perelmutter 2010). For the purpose of clarity, I reproduce a part of it not here but in the Notes ${ }^{4}$.

No cases of the combining of this verb with phrases "(preposition) $3 a+$ duration" have 
come to our notice. The only perfective correlate the verb has is the verb cxodumb. We argue that its meaning does not contain the feature "moving back". The verb freely occurs with the word "обратно", therefore there is no pleonasm, see the illustrations from the RNC: Позднее я убедился, что половина жителей поселка никогда не удалялись от него на расстояние, большее, чем нужно для того, чтобы за один день сходить в тундру и вернуться обратно; Пока Ефим сидел и думал над своим бюллетенем в кабине, Степа успел сходить в гастроном на Тираспольской площади и вернуться обратно; «Сходи, взгляни и, не показываясь, уходи обратно; Хей-ба-тоу хотел ещё один раз сходить на реку Самаргу и вернуться обратно 5 . Secondly, sentences like Ходила с папой в Литфонд к глазному врачу, оттуда прошли на Литейный в книжные магазиныл... (RNC) are completely grammatical. The perfective does not possess the meaning "result" either: Тот сходил в алтарь, но вылел ни с чем (RNC); $O$ местонахождении пролетариата у Чарнолуского было весьма приблизительное представление: он даже сходил за консультацией к Бронштейну, но тот обругал его и выставил (RNC). With all that said, we claim that the final perfective cxoдить is a purely aspectual counterpart of non-homogeneous intransitive xoдumb.

\section{Conclusion}

The aim of the paper is twofold. First is to demonstrate that researchers who attempt to describe the meaning of the traditionally postulated verbs like $u \partial m u-x о \partial u m b$ encounter the same difficulties. As a result, despite the wealth of inspiring ideas there is still no unanimously accepted semantic description of the verbs. The second goal is to suggest and substantiate a new approach to investigating Russian locomotion verbs. Note that by these verbs I mean not only the verbs of the type examined above but also the rest locomotion verbs. The backbone of the approach is differentiating homonymous locomotion verbs. 
From this perspective, one can see, for instance, that there are four homonymous directional verbs $и д m u$ and four homonymomus non-directional verbs xодumb in Russian. In this paper, I show that these homonyms differ with regard to their distributive potential, to the ability to have the actual-durative meaning and to their perfective counterparts. Each directional homonym has a non-directional counterpart, and vice-versa.

The suggested explanation employs no other devices beyond those commonly accepted; cf. (Janda 2010: 126). We claim that the key to the description of Russian locomotion verbs is reconsidering them with regard to the features 'telicity' and 'transitivity'. It appears that the produced description of the primary locomotion verbs in Russian satisfies the requirements of being consistent within itself, comprehensive and as simple as possible.

The results have been obtained due to consistent applying the classical structuralist methods of distributional analysis and oppositional analysis and also the general method of system analysis.

\section{References}

Apresjan, Ju.D. / Апресян Ю.Д. (2013). Бегать и бежать: словарные статьи "Активного словаря русского языка". In Московский лингвистический журнал, 15, p. 46-74. Available at: http://mjl.rsuh.ru/issues/issue15.html

Apresjan, Ju.D. / Апресян Ю.Д. (2011). Вид в активном словаре русского языка. In Глагольный вид: грамматическое значение и контекст. III Конференщия Комиссии по Аспектологии Международного Комитета Славистов (30 сентября - 4 октября 2011 г.). Падуя: Падуанский университет, р. 4-9.

Apresjan, Ju.D. / Апресян Ю.Д. (1990). Дистрибутивный анализ. In Лингвистический энщиклопедический словарь. Yartseva, V.N. (ed.) / Ярцева В.Н. (гл. ред.). Москва: Советская энциклопедия, р. 137-138. 
Apresjan, Ju.D. / Апресян Ю.Д. (1995а). Избранные трудыл. Т. 1: Лексическая семантика. Москва: Школа "Языки русской культуры".

Apresjan, Ju.D. / Апресян Ю.Д. (1995b). Избранные труды. Т. 2: Интегральное описание языка и системная лексикография. Москва: Школа "Языки русской культуры".

Apresjan, Ju.D. / Апресян Ю.Д. (1995c). Типы информации для поверхностносемантического компонента модели "Смысл $<=>$ Текст". In Ю.Д. Апресян. Избранные труды. Т. 2: Интегральное описание языка и системная лексикография. Москва: Школа "Языки русской культуры", р. 8-101.

Apresjan, Ju.D. / Апресян Ю.Д. (1967). Экспериментальное исследование семантики русского глагола. Москва: Наука.

Ballet flats Ronzo - review / Балетки Ronzo - отзыв. Available at: http://irecommend.ru/content/baletki-dlya-pytok-prekrasnogo-pola-foto .

Dickey, S.M. (2010). Common Slavic "indeterminate" verbs of motion were really manner-of-motion verbs. In New approaches to Slavic verbs of motion. Hasko, V. \& Perelmutter, R. (eds.). Amsterdam: John Benjamins, p. 67-109.

The dictionary of the modern Russian literary language / Словарь современного русского литературного языка. (1991). Gorbachevich, K.S. (ed.). / Горбачевич К.С. (ред.). Т.1. Москва: Русский язык.

Edootoj boo / Eдоотой боо. Available at: http://bg.ru/society/edootoy_boo-2479/

Glovinskaja, М.Ја. / Гловинская М.Я. (2001). Многозначность и синонимия в видовременной системе русского глагола. Москва: "Азбуковник": "Русские словари".

Grammar of the modern Russian literary language / Грамматика современного русского литературного языка. (1970). Shvedova N.Ju. (ed.). / Шведова, Н.Ю. (ред.). Москва: Наука.

Grammar of the Russian language / Грамматика русского языка. (1953). Vinogradov, 
V.V., Istrina, E.S. \& Barkhudarov, S.G. (eds.). / Виноградов В.В., Истрина Е.С., Бархударов С.Г. (ред.). Т. 1: Фонетика и морфология. Москва: Издательство АН CCCP.

Hasko, V. (2010). Semantic composition of motion verbs in Russian and English: The case of intra-typological variability. In New approaches to Slavic verbs of motion. Hasko, V. \& Perelmutter, R. (eds.). Amsterdam: John Benjamins, p. 197-223.

Hasko, V. \& Perelmutter, R. (2010). Verbs of motion in Slavic languages: paths for exploration. In New approaches to Slavic verbs of motion. Hasko, V. \& Perelmutter, R. (eds.). Amsterdam: John Benjamins, p. 1-11.

Hunting dogs: A brief decsription / Охотничьи породы собак: Краткая характеристика пород. Available at: http://okdzks.com/page.php?id=108.

Isachenko, A.V. / Исаченко A.В. (1960). Грамматический строй русского языка в сопоставлении со словацким. Ч. 2: Морфология. Братислава: Издательство Словацкой Академии Наук.

Janda, L.A. (2010). Perfectives from indeterminate motion verbs in Russian. In New approaches to Slavic verbs of motion. Hasko, V. \& Perelmutter, R. (eds.). Amsterdam: John Benjamins, p. 125-139.

Jakobson, R. (1984). Relationship between Russian stem suffixes and verbal aspects. In Jakobson, R. Russian and Slavic grammar. Berlin - New York-Amsterdam: Mouton, p. 27-31.

Kachurin, D.V. / Качурин Д.В. (2013). Проблема разграничения омонимии и полисемии применительно к практике составления толковых словарей. Дисс. ... канд. филол. н. Специальность 10.02.01 - Русский язык. Москва. Available at: http://www.ruslang.ru/doc/diss/kachurin.pdf

Kagan, O. (2010). Aspects of motion: On the semantics and pragmatics of indeterminate aspect. In New approaches to Slavic verbs of motion. Hasko, V. \& Perelmutter, R. (eds.). Amsterdam: John Benjamins, p. 141-162. 
Karcevski, S. / Карцевский С.И. (2004а). Заметки о психологии видов в русском языке. In C.И. Карцевский. Из лингвистического наследия. Т. 2. Москва: Языки славянской культуры, р. 221-238.

Karcevski, S. / Карцевский С.И. (2000). Повторительный курс русского языка. In Карцевский С.И. Из лингвистического наследия. Т. 1. Москва: Школа "Языки русской культуры", р. 97-204.

Karcevski, S. / Карцевский С.И. (2004b). Понятие процесса в русском языке. In С.И. Карцевский. Из лингвистического наследия. Т. 2. Москва: Языки славянской культуры, р. 209-220.

Karcevski, S. / Карцевский С.И. (2004c). Система русского глагола. In С.И. Карцевский. Из лингвистического наследия. Т. 2. Москва: Языки славянской культуры, р. 31-207.

Kobozeva, I.M. / Кобозева И.М. (2000). Лингвистическая семантика. Москва: Эдиториал УРСС.

Koptjevskaja-Tamm, M., Divjak, D. \& Rakhilina, E.V. (2010). Aquamotion verbs in Slavic and Germanic: A case study in lexical typology. In New approaches to Slavic verbs of motion. Hasko, V. \& Perelmutter, R. (eds.). Amsterdam: John Benjamins, p. 315-341. Lapshin, G. / Лапшин Г. Автостопом через Африку. Available at: http://www.rulit.me/books/avtostopom-cherez-afriku-read-247766-29.html

Lomtev, Т.Р. / Ломтев Т.П. (1976). Общее и русское языкознание. Избранные работыл. Москва: Наука.

Majsak, T.A. \& Rakhilina, E.V. / Майсак T.A., Рахилина Е.В. (1999). Семантика и статистика: глагол идти на фоне других глаголов движения. In Логический анализ языка: языки динамического мира. Арутюнова, Н.Д., Шатуновский, И.Б. (ред.). Дубна: Международный университет "Дубна", р. 53-66.

Maslov, Ju.S / Маслов Ю.С. (2004). Избранные труды: Аспектология. Общеее языкознание. Москва: Языки славянской культуры. 
Message board / Форум. Available at:

http://www.yaplakal.com/forum13/st/50/topic972040.html

Miloslavskiy, I.G. / Милославский И.Г. (1999). Морфология. In Современнылй русский язык. Белошапкова В.А. (ред.). Москва: Азбуковник, р. 442-605.

Nesset, T. (2010). Metaphorical walking: Russian idti as a generalized motion verb. In New approaches to Slavic verbs of motion. Hasko, V. \& Perelmutter, R. (eds.). Amsterdam: John Benjamins, p. 343-359.

New approaches to Slavic verbs of motion. (2010). Hasko, V. \& Perelmutter, R. (eds.). Amsterdam: John Benjamins.

Nichols, J. (2010). Indeterminate motion verbs are denominal. In New approaches to Slavic verbs of motion. Hasko, V. \& Perelmutter, R. (eds.). Amsterdam: John Benjamins, p. 47-65.

Okano, К. / Окано К. (2015). Лексико-семантические особенности глаголов перемещения в сербском и русском языках. In The Serbian language as viewed by the East and the West: Synchrony, diachrony, and typology. Popović, L. \& Nomachi, M. (eds.). Sapporo: Slavic Eurasian Research Center, Hokkaido University, p. 203-218.

Panov, M.V. / Панов M.В. (1999). Позиционная морфология русского языка. Москва: Школа "Языки русской культуры".

Perelmutter, R. (2010). Verbs of motion under negation in Modern Russian. In New approaches to Slavic verbs of motion. Hasko, V. \& Perelmutter, R. (eds.). Amsterdam: John Benjamins, p. 163-193.

Peshkovskiy, A.M. / Пешковский A.M. (1956). Русский синтаксис в научном освещении. Москва: Государственное учебно-педагогическое издательство МП РСФСР.

Petrukhina, E.V. / Петрухина Е.В. (2012). Аспектуальные категории глагола в русском языке в сопоставлении с чешским, словачким, польским и болгарским языками. Москва: URSS: Либроком. 
Plungian, V.A. / Плунгян В.А. (2011). Введение в грамматическую семантику: грамматические значения и грамматические системы языков мира. Москва: РГГУ. Rakhilina, E.V. / Рахилина E.В. (2000). Стой, кто идёт? In Слово в тексте и в словаре. Иомдин Л.Л., Крысин Л.П. (eds.). Москва: Школа "Языки русской культуры", р. 224-230.

Rakhilina, E. (2004). There and back: the case of Russian 'go'. Glossos, 5, p. 1-33. Available at: https://slaviccenters.duke.edu/uploads/media_items/5rakhilina.original.pdf. Russian grammar / Русская грамматика. (1980). Shvedova, N.Ju. et al. (eds.) / Шведова Н.Ю. и др. (ред.). Т. 1. Москва: Наука.

The Russian Language / Русский язык. (1998). Karaulov, Ju.N. (ed.). / Караулов Ю.Н. (ред.). Москва: Большая Российская энциклопедия: Дрофа.

Shakhmatov, A.A. / Шахматов A.A. (1941a). Очерк современного русского литературного языка. Москва: Учпедгиз.

Shakhmatov, A.A. / Шахматов А.А. (1941b). Синтаксис русского языка. Москва: Учпедгиз.

Sheljakin, M.A. / Шелякин М.A. (2001). Функциональная грамматика русского языка. Москва: Русский язык.

Susov, I.P / Сусов И.П. (1999). История языкознания. Available at: http://www.lib.ru/TEXTBOOKS/yazykoznanie.txt

The letter has called for the journey. The royal path / Письмо позвало в дорогу. Королевская mpona. Available at: http://www.otzyv.ru/read.php?id=192933.

The system of sportsmen training in racewalking / Система тренировки спортсменов в спортивной ходьбе. Available at: http://diplomba.ru/work/50589

Zaliznyak, A.A., Mikaelian, I.L. \& Shmelev, A.D. / Зализняк А.А., Микаэлян И.Л., Шмелёв А.Д. (2015). Русская аспектология: В защчиту видовой пары. Москва: "Языки славянской культуры". 


\section{Notes:}

1. This idea was brought into my view by the founder of the aspectological theory I follow.

2. One can see the similarity of the viewpoint we have accepted to Alexander Potebnja's perspective, cf., e.g., this statement of the scholar: "It is accepted in dictionaries that... under one acoustical complex all its meanings are listed. Such a custom is necessary but it should not produce the opinion that a word can have several meanings" (quoted as in (Качурин 2013: 19)).

3. Here we do not motivate our decision to qualify the verbs postulated as directional / non- directional. It is the topic of another paper we are preparing for publication.

4. Using detailed statistical frequencies Perelmutter demonstrates clearly that the behavior of traditionally postulated motion verbs in affirmative and negative sentences differ drastically (Perelmutter 2010). Below we quote some Perelmutter's data (she calculated using the verbs in Past tense) that reveal parallels with the results we have obtained with regard to the verbs used in Imperative.

Table 3 (a). Data from Table 1 in (168).

\begin{tabular}{|l|r|r|r|r|r|}
\hline \multicolumn{1}{|c|}{ Verb } & \multicolumn{2}{|c|}{ Negative } & \multicolumn{2}{c|}{ Affirmative } & \multicolumn{1}{c|}{ Total } \\
\hline xodil & 661,000 & $11.74 \%$ & $4,970,000$ & $88.26 \%$ & $5,631,000$ \\
\hline šel & 383,000 & $4.94 \%$ & $7,370,000$ & $95.06 \%$ & $7,753,000$ \\
\hline plaval & 32,900 & $6.49 \%$ & 474,000 & $93.51 \%$ & 506,900 \\
\hline plyl & 982 & $0.15 \%$ & 674,000 & $99.85 \%$ & 674,982 \\
\hline
\end{tabular}

Table 3 (b). Data from Table 2 in (168-171).

\begin{tabular}{|l|r|r|r|r|r|}
\hline \multicolumn{1}{|c|}{ Verb } & \multicolumn{2}{|c|}{ Negative } & \multicolumn{2}{c|}{ Affirmative } & \multicolumn{1}{c|}{ Total } \\
\hline xodil & 598,000 & $11.99 \%$ & $4,390,000$ & $88.01 \%$ & $4,988,000$ \\
\hline šel & 309,000 & $5.25 \%$ & $5,580,000$ & $94.75 \%$ & $5,889,000$ \\
\hline letal & 127,000 & $13.55 \%$ & 810,000 & $86.45 \%$ & 937,000 \\
\hline letel & 20,100 & $2.38 \%$ & 825,000 & $97.62 \%$ & 845,100 \\
\hline plaval & 33,800 & $6.55 \%$ & 482,000 & $93.45 \%$ & 515,800 \\
\hline plyl & 8,900 & $1.99 \%$ & 438,000 & $98.01 \%$ & 446,900 \\
\hline polzal & 16,100 & $7.42 \%$ & 201,000 & $92.58 \%$ & 217,100 \\
\hline polz & 3,880 & $1.34 \%$ & 285,000 & $98.66 \%$ & 288,880 \\
\hline
\end{tabular}


Table 3 (c). Data from Table 4 in (186).

\begin{tabular}{|l|r|r|r|r|}
\hline \multicolumn{1}{|c|}{ Verb } & \multicolumn{2}{c|}{ Negative } & \multicolumn{2}{c|}{ Affirmative } \\
\hline xodil & 598,000 & $30.40 \%$ & $4,390,000$ & $21.66 \%$ \\
\hline šel & 309,000 & $15.71 \%$ & $5,580,000$ & $27.53 \%$ \\
\hline pošel & $1,060,000$ & $53.89 \%$ & $10,300,000$ & $50.81 \%$ \\
\hline ezdil & 320,000 & $44.08 \%$ & $3,240,000$ & $35.22 \%$ \\
\hline exal & 59,900 & $8.25 \%$ & $2,600,000$ & $28.26 \%$ \\
\hline poexal & 346,000 & $47.66 \%$ & $3,360,000$ & $36.52 \%$ \\
\hline letal & 127,000 & $63.34 \%$ & 810,000 & $31.40 \%$ \\
\hline letel & 20,100 & $10.02 \%$ & 825,000 & $31.98 \%$ \\
\hline poletel & 53,400 & $26.63 \%$ & 945,000 & $36.63 \%$ \\
\hline plaval & 33,800 & $67.74 \%$ & 482,000 & $36.54 \%$ \\
\hline plyl & 8,900 & $17.84 \%$ & 438,000 & $33.21 \%$ \\
\hline poplyl & 7,200 & $14.43 \%$ & 399,000 & $30.25 \%$ \\
\hline polzal & 16,100 & $71.78 \%$ & 201,000 & $24.16 \%$ \\
\hline polz & 3,880 & $17.30 \%$ & 285,000 & $34.25 \%$ \\
\hline popolz & 2,450 & $10.92 \%$ & 346,000 & $41.59 \%$ \\
\hline
\end{tabular}

One can see that the researcher whose perspective radically differs from that I develop notices that the traditionally postulated verbs $и д т и$ and ходить behave differently in affirmative and negative sentences.

5. The RNC provides with perfect examples of other locomotion perfectives of the type: Я сбегала вниз, обнаружила на двери замок и вернулась обратно; Он уже оформил груз и пассажиров (вместо Вовочки - это была его задача), сбегал на "метео" и обратно и встретил нас, когда уже собирался подняться к диспетчерам; А то сбегай в Свистуново туда и обратно - ровно столько же в один конеи и до Тиханова будет; Айдым поняла все; она сбегала обратно к народу на ночлег, но все люди уже тронулись оттуда к стаду, кто как мог: кто полз, кто шевелился на ногах, кто пользовался помощью другого; Абдулка сбегал обратно во двор отия Павладия, обошел снова все комнаты священника, поставил на место к киоту свечу, запер все двери, снял веревку с ног и с рук тетки Горпины, не чувствовавщей с похмелья ничего бывшего в ту ночь с нею, перемагнул опять через нее и снова 
побежал к коляске; Я сплавал на большой остров и начал натягивать кеды на мокрые ноги; Прохор фыркал, отдувался, гоготал, сплавал на ту сторону, нарвал фиалок и ияарских кудрей, расцветил букет огнями желтых лилий и поплыл обратно; Филипп сплавал туда-сюда, перевез самых нетерпеливых, дальше пошло легче, без нервов.

\begin{tabular}{|l|l|l|}
\hline \multicolumn{2}{|c|}{ Contact data } & \multicolumn{2}{c|}{ Fields of interest } \\
Nezrin Samedova, PhD, \\
senior lecturer at the \\
Department of General \\
Linguistics at Azerbaijan \\
University of Languages, \\
49, R. Behbudov str., Baku, \\
Azpectology, Russian \\
verb, Russian grammar. \\
Aspectological Commission \\
of the International \\
Committee of Slavists \\
e-mail: \\
nezrin.samedova@gmail.com
\end{tabular}

\section{Résumé (in English)}

As part of a larger study, this paper has two objectives. The first is to analyse discussions about the semantic description of traditionally postulated verbs of locomotion like $u д m u$ /to go/-xodumb/to walk/. The analysis reveals that there are very few ideas on the nature of the verbs that are uncontroversial. Thus, researchers discuss how exactly these verbs differ from the rest of verbs of locomotion, what semantic specificity verbs like $u \partial m u$ and ходиmb possess, what their characterization with regard to the category telicity / atelicity is, if they have purely aspectual counterparts. The second objective is to propose a theory that not only incorporates ideas of several generations of eminent researchers but is also consistent within itself, comprehensive and as simple as possible. Developing such a theory has become possible because the traditionally postulated verbs of locomotion have been reconsidered in the light of the features 'telicity' /'atelicity' and 'transitivity'/ 
'intransitivity'. In other words, whereas the traditional description postulates one intransitive verb, it is suggested instead to differentiate four following homonymous locomotion verbs: the homogeneous transitive one, the homogeneous intransitive one, the non-homogeneous transitive one and the non-homogeneous intransitive one. Thus, one of the results obtained is that I show that homogeneous and non-homogeneous locomotion verbs should be differentiated consistently. The explanatory power of the theory is demonstrated through describing four homonymous directional verbs $и \partial m u$ and four homonymous non-directional verbs xodumb. In this paper, the author shows that these homonyms differ with regard to their distributive potential, to the ability to have the actual-durative meaning and to their perfective counterparts. Each directional homonym has a non-directional counterpart, and vice-versa. The results have been achieved due to consistently applying the classical structuralist methods of distributional analysis and oppositional analysis and also the general method of system analysis. There are grounds to think that the results can be extrapolated to the rest of Russian locomotion verbs.

Keywords: verbs of directional locomotion like $u \partial m u$, verbs of non-directional locomotion like xодumb, homogeneous transitive verbs of locomotion like $u \partial m u_{1}$ and like ходить ${ }_{1}$, homogeneous intransitive verbs of locomotion like $и д т u_{2}$ and like $х о д и т \boldsymbol{r}_{2}$, non-homogeneous transitive verbs of locomotion like $u д т u_{3}$ and like оодить $_{3}$, nonhomogeneous intransitive verbs of locomotion like $u \partial m u_{4}$ and like $x_{o \partial u m b_{4}}$.

\section{Résumé (in German)}

Vorliegender Artikel stellt Ihnen eine der Serien der Forschungen hinsichtlich der der Bewegungsverben in der russischen Sprache vor. Darin stellt der Autor vor sich zwei Zwecke. Im Ersten- Analyse der subsistierten Meinung über Semantik der postulierten Bewegungsverben vom Тур идти und ходить. Infolge der Analyse hat sich ergeben, dass in allen Fragen über Entwicklungsperiode dieser Verben seriöse 
Meinungsverschiedenheiten bestehen. Denn die Erforscher nehmen auseinander, dass diese Verben sich von den anderen Bewegungsverben unterscheiden, in der semantische Eigenartigkeit der Verben vom Тур идти oder ходить, ebenso ihre Charakteristik in Bezug auf Kategorie der Grenzbedeutung/Nichtgrenzbedeutung besitzen, sowie bei ihnen vorhandene rein förmliche Korrelate. Zweites Ziel besteht aus dem Vorschlag zur vollständigen und einfachen Lösung dieser Frage, die nicht nur den Ideen der einigen Generationen der angesehenen Sprachwissenschaftler entsprochen, sondern auch nicht widergesprochen hätten. Die Bearbeitung solcher Entscheidung kann in solchem Fall möglich werden, in dem Autor die Charakteristik der Bewegungsverben aus dem Standpunkt der Merkmale 'Aktionsart' und 'Transitivität' präzisieret wird. Mit anderem Wort-falls traditionelle Beschreibung postuliert ein intransitives Verb, schlägt Autor vor, vier nachfolgende homonyme Bewegungsverben abzugrenzen: homogenes transitives Verb, inhomogenes transitives Verb und inhomogenes intransitives Verb. Solchermaßen wird eines der erreichten Ergebnisse davon bestehen, dass ich darin die Notwendigkeit der konsequenten Abgrenzung der homogenen und inhomogenen Bewegungsverbe zeige. Explikatives Potential der angebotenen Theorie wird im Muster der vier homonymen Richtungsverben $u \partial m u$ und vier homonymen Nichtrichtungsverben $x о \partial u m ь$ demonstriert. Im vorliegen Artikel weise ich nach, dass diese Homonyme aus dem Standpunkt des Valenz-Potentials, der Fähigkeit, ebenso dem Korrelataspekt von der aktuellen Bedeutung sind. Jede Richtung des Homonyms besitzt nicht gerichtetes Korrelat oder umgekehrt. Vorliegende Ergebnisse waren dank der konsequenten Anwendung der klassischen Strukturmethoden der distributiven Analyse, Oppositionsanalyse, ebenso der allgemeinen Methode der Systemanalyse erreicht. Es gibt die Grundlage darüber zu vermuten, dass dargestellte Ergebnisse für andere Bewegungsverbe in der russischen Sprache extrapoliert werden. 
Stichwörter: Richtungsverbe vom Bewegungstyp $и д m u$, Nichtrichtungsverbe vom Bewegungstyp ходиmь, homogene transitive Verbe vom Bewegungstyp $и д т u_{1}$ und vom Tyр ходиmь ${ }_{1}$, homogene intransitive Verbe vom Bewegungstyp $и д т u_{2}$ oder vom Typ ходить $b_{2}$, inhomogene transitive Verbe vom Bewegungstyp $и д т u_{3}$ und vom Тур ходить inhomogene intransitive Verbe vom Bewegungstyp $и д т u_{4}$ und vom Тур ходить

\section{Résumé (in French)}

Cet article fait partie d'une série des travaux de recherche des verbes de mouvement en russe. Dans le présent article, l'auteur se fixe sur deux objectifs. Le premier objectif est d'analyser les opinions existantes sur la sémantique des verbes traditionnellement postulés de mouvement comme $и \partial m u$ et xoдumb. L'analyse a révélé que presque toutes les questions sur la nature de ces verbes sont discutées. Ainsi, les chercheurs disputent sur ce que ces verbes se distinguent des autres verbes de mouvement, quelle est la particularité sémantique des verbes tel que $и \partial m u$ et $х о д u m b$, quelles sont leurs caractéristiques par rapport à la catégorie de télicité/ non-télicité, s'ils ont des corrélats aspectuel pures. Le deuxième objectif est d'offrir une solution qui absorbe non seulement les idées de plusieurs générations des linguistes éminents, mais qui est aussi cohérente, compléte et en même temps extrêmement simple. Le développement d'une telle solution est rendu possible par ce que l'auteur propose de spécifier la description des verbes de mouvement par rapport à la caractéristique de 'télicité' et 'transitivité'. En d'autres termes, si la description traditionnelle postule un verbe intransitif, l'auteur propose de distinguer les quatre verbes de mouvements homonymes suivants: verbe homogène transitif, verbe homogène intransitif, verbe non-homogène transitif et verbe non-homogène intransitif. Ainsi, un de ces résultats réside dans le fait que l'auteur montre la nécessité de délimitation consécutive des verbes homogènes de mouvement et des verbes non-homogènes de mouvement. Le potentiel explicatif de la théorie proposée est présenté par un exemple de quatre verbes homonymes directionnels $и \partial m u$ et de quatre verbes homonymes non-directionnels 
xодumb. Dans cet article, l'auteur montre que ces homonymes sont différents par rapport à leur potentiel compatible, leur capacité à avoir le sens du présent actuel, ainsi que leurs corrélats pures aspectuels. Chaque homonyme directionnel a un corrélat non-directionnel, et au contraire. Ces résultats ont été obtenus grâce à l'application consécutive des méthodes structuralistes classiques de l'analyse distributive, l'analyse de l'opposition, ainsi que d'une méthode générale d'analyse du système. Il y a des raisons de croire que les résultats susdits peuvent être extrapolés au reste des verbes de mouvement en russe.

Mots-clés: les verbes directionnels de mouvement tels que $и \partial m u$, les verbes nondirectionnels de mouvement tels que xoдumb, les verbes homogènes transitifs de mouvement tels que $и д m u_{1}$ et $х о д и m b_{1}$, les verbes homogènes intransitifs de mouvement tels que $u \partial m u_{2}$ et $x о \partial u m b_{2}$, les verbes non-homogènes transitifs de mouvement tels que $u д т u_{3}$ et $х о д и m b_{3}$ et les verbes non-homogènes intransitifs de mouvement tels que $u \partial m u_{4}$ et xodumb4.

\section{Résumé (in Russian)}

Данная статья представляет собой одну из серии работ по исследованию глаголов передвижения в русском языке. В настоящей работе автор ставит перед собой две цели. Первая - проанализировать существующие мнения о семантике традиционно постулируемых глаголов передвижения типа идти и типа ходить. В результате анализа обнаруживается, что фактически по всем вопросам о природе этих глаголов имеются серьёзные разногласия. Так, исследователи спорят о том, чем именно данные глаголы отличаются от остальных глаголов передвижения, в чём семантическое своеобразие глаголов типа идти и глаголов типа ходить, какова их характеристика в отношении к категории предельности / непредельности, есть ли у них чистовидовые корреляты. Вторая цель состоит в том, чтобы предложить решение, которое не только впитает идеи нескольких поколений выдающихся 
языковедов, но также будет непротиворечивым, полным и при этом предельно простым. Разработка подобного решения становится возможной благодаря тому, что автор предлагает уточнить характеристику глаголов передвижения с точки зрения признаков 'предельность' and 'переходность'. Другими словами, если традиционное описание постулирует один непереходный глагол, автор предлагает разграничить четыре следующих омонимичных глагола передвижения: гомогенный переходный глагол, гомогенный непереходный глагол, негомогенный переходный глагол и негомогенный непереходный глагол. Таким образом, один из полученных результатов заключается в том, что я показываю необходимость последовательного разграничения гомогенных и негомогенных глаголов передвижения. Объяснительный потенциал предложенной теории демонстрируется на примере четырёх омонимичных направленных глаголов идти и четырёх омонимичных ненаправленных глаголов ходить. В настоящей статье автор показывает, что данные омонимы различаются с точки зрения их сочетаемостного потенциала, их способности иметь настоящее актуальное значение, а также со стороны чистовидовых коррелятов. Каждый направленный омоним имеет ненаправленный коррелят, и наоборот. Данные результаты получены благодаря последовательному применению классических структуралистских методов дистрибутивного анализа, оппозиционного анализа, а также общего метода системного анализа. Есть основания полагать, что изложенные результаты могут быть экстраполированы на остальные глаголы передвижения в русском языке.

Ключевые слова: направленные глаголы передвижения типа $u д т u$, ненаправленные глаголы передвижения типа ходить, гомогенные переходные

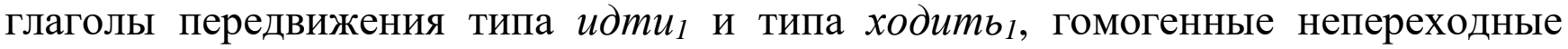
глаголы передвижения типа идти и и типа ходить 2, негомогенные переходные глаголы передвижения типа идтиз и типа ходитьз, негомогенные непереходные глаголы передвижения типа $u \partial m u_{4}$ и типа ходить4. 
Article was received by the editorial board 11.08.16;

Reviewed 30.08.16 and 2.10.16.

Similarity Index 4\%. 